\title{
Estimation of Growth Parameters of the Black Scallop Mimachlamys varia in the Gulf of Taranto (Ionian Sea, Southern Italy)
}

\author{
Ermelinda Prato *(D), Francesca Biandolino, Isabella Parlapiano, Loredana Papa, \\ Giuseppe Denti and Giovanni Fanelli \\ CNR/IRSA (National Research Council/Water Research Institute), Via Roma 3, 74100 Taranto, Italy; \\ francesca.biandolino@irsa.cnr.it (F.B.); isabella.parlapiano@irsa.cnr.it (I.P.); loredana.papa@irsa.cnr.it (L.P.); \\ giuseppe.denti@irsa.cnr.it (G.D.); giovanni.fanelli@irsa.cnr.it (G.F.) \\ * Correspondence: linda.prato@irsa.cnr.it
}

Received: 22 October 2020; Accepted: 26 November 2020; Published: 28 November 2020

\begin{abstract}
The present study examines the juvenile growth of nine cohorts of Mimachlamys varia in a coastal area of the Ionian Sea, from January 2014 to May 2015. The results showed that $M$. varia could reach commercial size in less than one year of cultivation, but significant differences in absolute growth rate (AGR) and specific growth rate (SGR) were found among cohorts $(p<0.05)$. Relationships between scallop growth (size and weight) and environmental variables (water temperature, dissolved oxygen and chlorophyll concentration) were also identified. The length-weight relationship showed negative allometric growth and indicated high correlation with $\mathrm{R}^{2}$, ranging from 0.95 to 0.82 . Von Bertalanffy growth parameters showed the highest values of $\mathrm{L}_{\infty}$ in the cohorts collected in January, April and February $\left(52.2,51.2\right.$ and 50.3), respectively. The growth performance index $\left(\varphi^{\prime}\right)$ ranged between 2.52 (cohort collected in June) and 3.03 (cohort collected in August). The obtained data add basic knowledge to the growth performance of this species, making this a good opportunity to facilitate aquaculture diversification in this part of Mediterranean Sea.
\end{abstract}

Keywords: bivalvia; black scallops; aquaculture; estimation growth; Ionian Sea

\section{Introduction}

The European Union promoted "Blue Growth" as a strategy to forward the core principles of environmentally smart, integrated and socio-economically sensitive management. This strategy aims to improve the access, utilization and production efficiency of natural resources in several maritime sectors. In light of this, aquaculture offers great potential for innovation, sustainable and inclusive growth within the marine sector [1,2].

European shellfish production is mainly based on oysters and mussels that together represent $93 \%$ of the total European cultivated mollusc production, while clams, cockles, ark shells and scallops are only responsible for a small European market share (about $16 \%$ in 2001) [3]. France is by far the leading producer of oysters $( \pm 85,000$ tonnes in 2011), Spain of mussels $( \pm 209,000$ tonnes in the same year) and Italy of clams $( \pm 32,000$ tonnes in the same year) [3].

In Italy, bivalve aquaculture is based mainly on Mediterranean mussels, Mytilus galloprovincialis, and Manila clams, Ruditapes philippinarum. Interest in the Pectinidae family, commonly known as scallops, has increased significantly in recent years [4]. They represent part of the global seafood market and support commercial fisheries and aquaculture all around the world [5]. Among them, the 'black' or 'variegated scallop', Mimachlamys varia, is a species, distributed from the North Sea to Senegal and along the Mediterranean Sea, that contributes little to European fisheries. In recent years, 
the main commercial exploitation of $M$. varia has been along the French Atlantic coast, particularly the eastern part of the Bay of Brest. In Italy, fishery of this bivalve occurs in small quantities through artisanal fisheries (dredges and trawls) that fail to meet domestic demand [6]. Dredges and trawls utilized in commercial fishing are also known to cause considerable damage and disturbance to benthic communities and associated nursery habitats [7]. It is currently successfully farmed on the Atlantic coast of France, Ireland and Spain [8], while Rathman et al. [9] report that the Adriatic Sea has good potential for $M$. varia mariculture. It is important to consider that literature data report that geographical factors markedly influence the growth of $M$. varia populations [9-11].

Recent studies have demonstrated that wild M. varia in the Ionian Sea waters are easily collected with artificial substrates, becoming the most frequent and abundant species among the settled bivalves on collectors [12]. This represents a favorable prerequisite for the development and optimization of technology for commercial cultivation, although the choice of potential candidates for aquaculture also presupposes the acquisition of deep knowledge of the physiology of growth of cultured species $[13,14]$.

The goal of this paper was to determine the growth patterns of $M$. varia in different periods of the year, cultured in suspended cages in the Ionian Sea, with the objectives of determining the most favorable period for the growth of this species and developing scallops' culture of commercial interest in the Central Mediterranean Sea.

\section{Materials and Methods}

\subsection{Study Area}

The Mar Grande of Taranto is a semi-enclosed basin in the Gulf of Taranto (Ionian Sea, Mediterranean Sea), extending for around $36 \mathrm{~km}^{2}$ with a maximum depth of $36 \mathrm{~m}$. It represents an important fishing area where many mussel farm plants are localized.

\subsection{Environmental Variables}

Several variables were measured at the experimental site (at a depth of 6-9 $\mathrm{m}$ ) in order to correlate growth results with environmental conditions. At all sampling times, a set of abiotic variables (temperature, salinity and dissolved oxygen) were directly measured at the culture site using an Idromar IM52 (Idromat International, San Giuliano Milanese, Milan, Italy) multiparametric probe. Moreover, seawater samples were collected from Niskins into clean polyethylene bottles and immediately filtered through $47 \mathrm{~mm}$ GF/F filters, and a chlorophyll-a concentration (as an indicator of phytoplankton biomass) was measured spectrophotometrically [15].

In this study, $90 \%$ acetone was used to measure the chlorophyll-a concentration at selected wavelengths. Modified formulae were used to measure the chlorophyll-a concentration value. Refer to Formulas (1) and (2). Prior to spectrophotometric analysis, all microalgae were extracted using centrifugation for $10 \mathrm{~min}$ at $4000 \mathrm{rpm}$ in a centrifuge machine. The absorbance of microalgae was measured using a spectrophotometer (model SHIMADZU 1800 UV-Visible spectrophotometer, Shimadzu Italia S.r.l., Milan, Italy).

In the spectrophotometer, $90 \%$ acetone was used as a blank. Then, the absorbance at $750 \mathrm{~nm}$ was subtracted from the three wavelengths to determine the turbidity-corrected value. To calculate the chlorophyll-a concentration, the formulae below were used:

$$
\begin{gathered}
\mathrm{Chl}-\mathrm{a}\left(\frac{\mu \mathrm{g}}{\mathrm{L}}\right)=(11.85 \times \mathrm{E} 664)-(1.54 \times \mathrm{E} 647)-(0.08 \times \mathrm{E} 630) \\
\text { Concentration of } \mathrm{Chl}-\mathrm{a}\left(\frac{\mathrm{mg}}{\mathrm{L}}\right)=[\mathrm{Chl}-\mathrm{a} \times \mathrm{v}] / \mathrm{V} \times \mathrm{L}
\end{gathered}
$$

in which:

$\mathrm{v}=$ Volume of acetone $90 \%, \mathrm{~L}$

$\mathrm{V}=$ Volume of water sample, $\mathrm{L}$ 
$\mathrm{L}=$ Light path of cuvette, $\mathrm{cm}$

E664 = Value of absorbance at wavelength $664 \mathrm{~nm}$

E647 = Value of absorbance at wavelength $647 \mathrm{~nm}$

E630 $=$ Value of absorbance at wavelength $630 \mathrm{~nm}$.

\subsection{Scallop Spat Collection}

From January to September 2014, polypropylene net-bags, arranged as spat collectors described by PRATO et al. (2015), were submerged in experimental long-line structures within a mussel plant in the Mar Grande of Taranto $\left(40^{\circ} 26^{\prime} 73^{\prime \prime} \mathrm{N}, 17^{\circ} 13^{\prime} 50^{\prime \prime} \mathrm{E}\right)$ (Figure 1). Since the presence of pediveligers deeper in the water column suggests that the deployment of collectors near the bottom ensures a high recruitment of scallop spats [16], the collectors were placed at 9-12 m depth. Each month, six collectors were immersed and then recovered and replaced by scuba divers after about 2-3 months, when the spat size showed an adequate mean size (about $1 \mathrm{~cm}$ ), making their handling easier for the purpose of culture practices. Each month, the settled spats were transferred in a pilot plant, where they were cultivated in suspended cages at a depth of 6-7 $\mathrm{m}$ in the Mar Grande of Taranto $\left(40^{\circ} 25^{\prime} 54^{\prime \prime} \mathrm{N}, 17^{\circ} 14^{\prime} 22^{\prime \prime}\right.$ E). The holding system consisted of round plastic crates, generally used to on-grow shellfish. The crates were made up of shallow cylindrical baskets $(11 \mathrm{~cm}$ high and $60 \mathrm{~cm}$ in diameter with a $1 \mathrm{~cm}$ mesh size and an available surface of about $0.25 \mathrm{~m}^{2}$ ), which stacked together and could be suspended by a single rope running vertically through the center of the stack. The top basket formed the lid of the basket below (Figure 2). From the immersion of the crates, the juveniles were maintained over approximately 15 months in these experimental conditions and sampled each month for morphologic measurements. Inside of the cages, stocking densities was about 150 juveniles per each replicate, and at sampling time, scallops were removed from baskets. Scallops were selected randomly, and care was taken to not apply any selection pressure on growth traits.

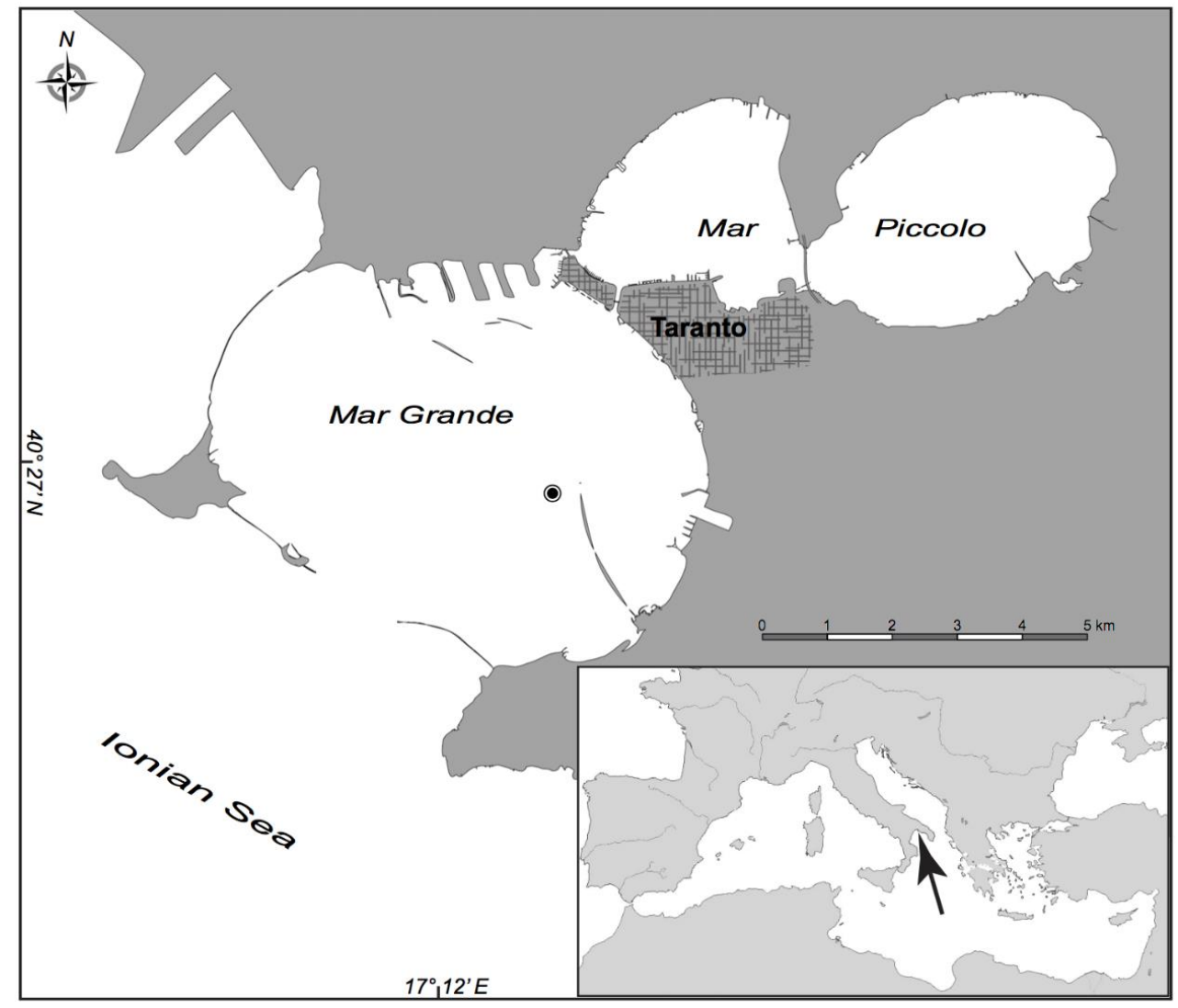

Figure 1. Location of the study sites in the Gulf of Taranto (Ionian Sea, Mediterranean Sea). 

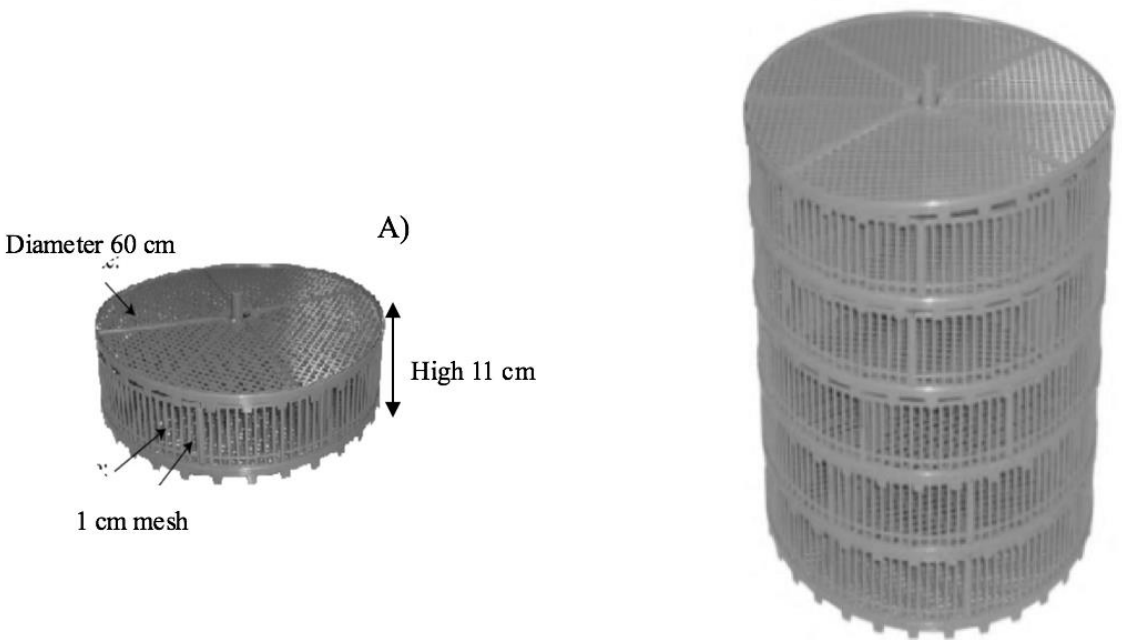

B)

Figure 2. Close-up of the round baskets used to grow Mimachlamys varia (A). Each basket was stacked and suspended by a rope running vertically through the center of the stack (B). The top basket formed the lid of the basket below.

\subsection{Growth}

At each sampling time, at least 30 individuals were randomly taken, the total length (LT: maximum length along the anterior-posterior axis) was measured using a stainless-steel caliper $(0.1 \mathrm{~mm})$, and the weight was measured with a digital balance to the nearest $0.1 \mathrm{~g}$ (TW: total weight).

The length-weight relationship was described using $\mathrm{W}=\mathrm{aTL}^{\mathrm{b}}$, according to the equation given by RICKER (1975), where $\mathrm{W}$ is total weight (g), TL is total length (mm), a is the intercept of the regression line and $b$ is the regression coefficient. The variation of $b$ values from 3 was tested by the $t$-test for evaluating growth curve. The value of $b$ is a good indicator of the type of growth: the growth is isometric if $b=3$ [17], and the growth is allometric if $b \neq 3$ (negative allometric if $b<3$ and positive allometric if $\mathrm{b}>3$ ) [18].

A paired Student's sample t-test was used to compare " $b$ " to 3, and the Pearson correlation was used to test the significance of all regressions.

At the end of experiment, growth rates of shell length and wet weight were reported as the absolute growth rate (shell length AGRl and weight AGRw) and specific growth rate (SGR) calculated according to the following equations:

$$
\begin{gathered}
\mathrm{AGR} l=(\mathrm{Lf}-\mathrm{Li}) / \mathrm{t} \\
\mathrm{AGR} w=(\mathrm{Wf}-\mathrm{Wi}) / \mathrm{t} \\
\mathrm{SGR}=\ln ((\mathrm{Lf})-\ln (\mathrm{Li})) / \mathrm{t} \times 100 \text { and } \mathrm{SGR} w=\ln ((\ln W \mathrm{f})-\ln (\mathrm{Wi})) / \mathrm{t} \times 100
\end{gathered}
$$

where:

$\mathrm{Lf}=$ final average shell length

$\mathrm{Wf}=$ wet weight at the end of the experiment

$\mathrm{Li}=$ initial average shell length

$\mathrm{Wi}=$ wet weight at the beginning of the experiment

$\ln =$ natural logarithm

$t=$ number of days of the experimental time.

The von Bertalanffy growth function (VBGF) [19] was used to estimate the growth of the nine cohorts. Estimates of growth parameters for each cohort were obtained by the use of electronic length 
frequency analysis (ELEFAN I) included in the FISAT (Fish Stock Assessment Tools) program [20], describing growth with the following equation:

$$
\mathrm{Lt}=\mathrm{L} \infty(1-\mathrm{e}-\mathrm{k}(\mathrm{t}-\mathrm{t} 0))
$$

where:

Lt: = length at age $\mathrm{t}$

$\mathrm{L}_{\infty}$ : asymptotic length

k: growth constant (rate at which length approaches $\mathrm{L}_{\infty}$ )

t0: theoretical age of an animal at a length equal to zero.

Theoretical von Bertalanffy growth parameters were calculated using the observed average shell lengths (TL) of the experimental scallops.

To compare the growth of $M$. varia among the cultures, the overall growth performance index $\left(\varphi^{\prime}\right)$ was calculated. The estimates of $\mathrm{L}_{\infty}$ and $\mathrm{K}$ were used to compute the $\varphi^{\prime}$ (in terms of length) of the species [21,22] with the following equation:

$$
\varphi^{\prime}=\log _{10} \mathrm{~K}+2 \log _{10} \mathrm{~L}_{\infty} .
$$

\subsection{Statistical Analysis}

Results are reported as means \pm standard deviations $(n=3)$. The normality of distributions and homogeneity of variances were assessed by means of the Kolmogorov-Smirnov test and the Levene's test, respectively. Data were subjected to a one-way ANOVA to test the growth parameters of all studied cohorts, and when significant differences were found, the mean values were subjected to post hoc analysis using Tukey's test $(p<0.05)$. When requirements for normality were not met, the non-parametric Kruskal-Wallis test on ranks was applied $(p \leq 0.05)$.

Relationships between scallop growth (size and weight) and environmental variables (water temperature, dissolved oxygen and chlorophyll concentration) were carried out using Pearson's correlation.

\section{Results}

The recorded monthly environmental parameters are shown in Figure 3. The annual mean of temperature showed significant differences (ANOVA, $p<0.05$ ), with maximum and minimum temperature values of $26.7^{\circ} \mathrm{C}$ in August and $14.2^{\circ} \mathrm{C}$ in February, respectively. Salinity did not display a defined pattern but remained within a very narrow range of $38.8 \pm 0.2$ psu (ANOVA, $p>0.05$ ). The mean dissolved oxygen was at its maximum in October and March, with 107 and $103 \mathrm{mg} / \mathrm{l}$, and at its minimum in August $(86.7 \mathrm{mg} / \mathrm{L}$ ) (ANOVA, $p<0.05)$. The $C h-a$ concentration in the water exhibited significant differences during the study period (ANOVA, $p<0.05$ ), with higher $C h$ - $a$ concentration values during winter and spring months (Figure 3). 

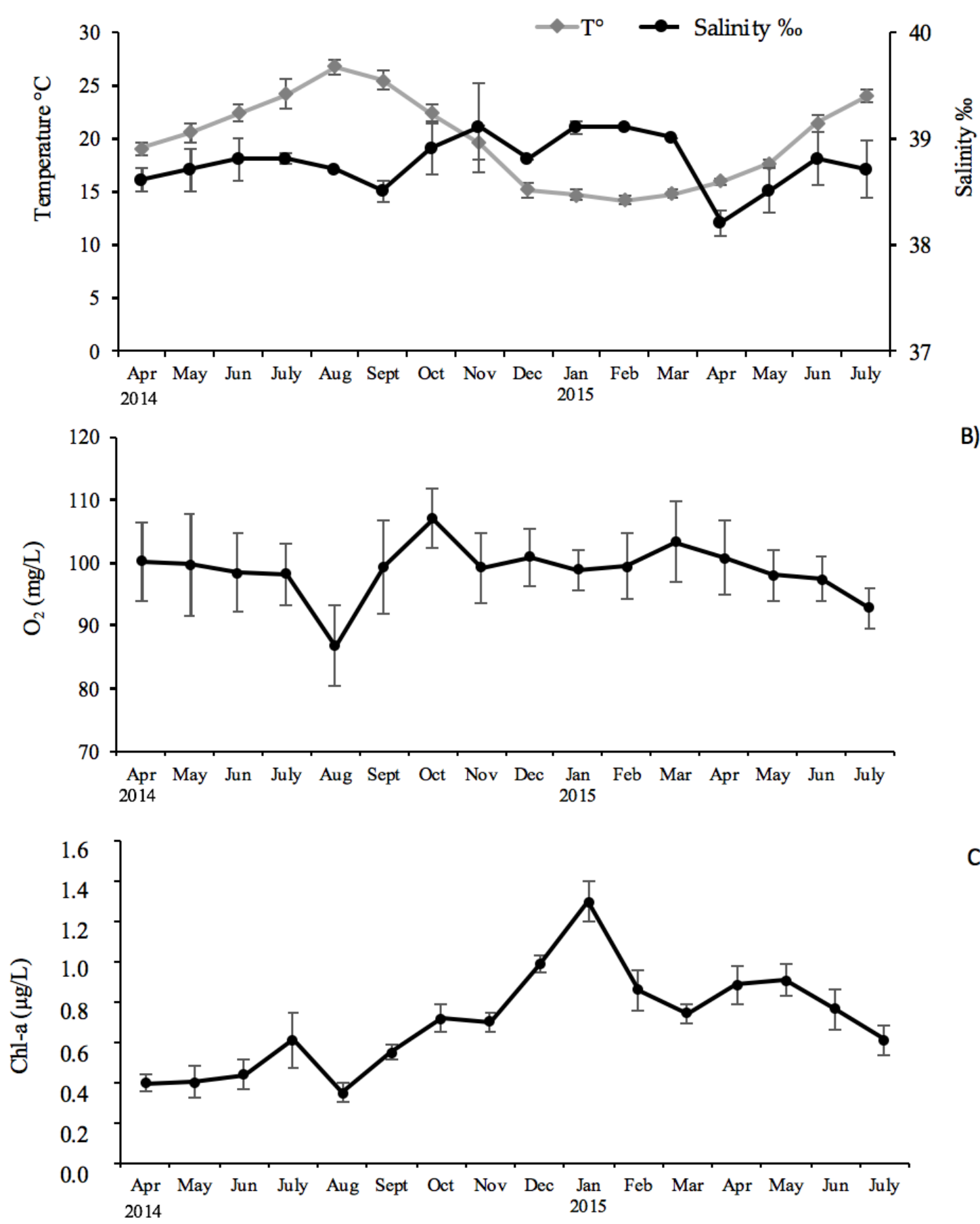

Figure 3. Mean ( \pm S.D.) monthly values of environmental variables during the experimental period. (A) Temperature $\left({ }^{\circ} \mathrm{C}\right)$ and salinity \%o, (B) dissolved oxygen $(\mathrm{mg} / \mathrm{L}),(\mathbf{C})$ chlorophyll a $(\mu \mathrm{g} / \mathrm{L})$.

The average initial shell length and total weight of the collected spat showed significant differences among the cohorts (ANOVA, $p<0.05$ ), ranging from $12.7 \mathrm{~mm}$ and $0.3 \mathrm{~g}$ for Coh B-Feb (the spat that came from collectors immersed in February and collected after 42 days) to $26.8 \mathrm{~mm}$ and $2.50 \mathrm{~g}$ for Coh C- Mar (the spat from collectors immersed in March and retrieved after 69 days) (Tables 1 and 2). 
Table 1. Timing of immersion of spat collectors for all cohorts, starting dates of juveniles' growth in suspended cages, and sampling dates of morphological measurements of juveniles maintained in experimental rearing conditions. For all cohorts, Maximum Estimated Age (MEA) of cultured scallops was estimated by counting the days from the immersion of collectors.

\begin{tabular}{|c|c|c|c|c|c|c|c|c|c|c|c|}
\hline $\begin{array}{l}\text { Immersion } \\
\text { Date of } \\
\text { Collectors }\end{array}$ & $\begin{array}{l}\text { Ongrowing } \\
\text { Starting } \\
\text { Date }\end{array}$ & $\begin{array}{l}\text { Biometric } \\
\text { Measurement } \\
\text { Date }\end{array}$ & MEA & $\begin{array}{c}\text { Immersion } \\
\text { Date of } \\
\text { Collectors }\end{array}$ & $\begin{array}{c}\text { Starting } \\
\text { Date in } \\
\text { Suspended } \\
\text { Cages }\end{array}$ & $\begin{array}{l}\text { Biometric } \\
\text { Measurement } \\
\text { Date }\end{array}$ & MEA & $\begin{array}{l}\text { Starting } \\
\text { Date in } \\
\text { Suspended } \\
\text { Cages }\end{array}$ & $\begin{array}{l}\text { Biometric } \\
\text { Measurement } \\
\text { Date }\end{array}$ & $\begin{array}{l}\text { Sampling } \\
\text { Date }\end{array}$ & MEA \\
\hline Cohort A & $01 / 04 / 14$ & $01 / 04 / 14$ & 62 & Cohort D & $13 / 06 / 14$ & $13 / 06 / 14$ & 51 & Cohort G & $17 / 10 / 14$ & $17 / 10 / 14$ & 85 \\
\hline \multirow[t]{7}{*}{ 29/01/14 } & & $13 / 05 / 14$ & 104 & $23 / 04 / 14$ & & 05/08/14 & 104 & $14 / 07 / 14$ & & $04 / 11 / 14$ & 113 \\
\hline & & $27 / 06 / 14$ & 149 & & & $18 / 09 / 14$ & 148 & & & $21 / 11 / 14$ & 157 \\
\hline & & $05 / 08 / 14$ & 188 & & & $21 / 10 / 14$ & 181 & & & $17 / 12 / 14$ & 183 \\
\hline & & $18 / 09 / 14$ & 232 & & & $04 / 11 / 14$ & 195 & & & $21 / 01 / 15$ & 218 \\
\hline & & $21 / 10 / 14$ & 265 & & & $17 / 12 / 14$ & 238 & & & $24 / 02 / 15$ & 252 \\
\hline & & $17 / 12 / 14$ & 322 & & & $21 / 01 / 15$ & 273 & & & $31 / 03 / 15$ & 287 \\
\hline & & $21 / 01 / 15$ & 357 & Cohort E & 05/08/14 & $05 / 08 / 14$ & 84 & & & $28 / 04 / 15$ & 315 \\
\hline Cohort B & 01/04/14 & $01 / 04 / 14$ & 42 & $13 / 05 / 14$ & & $18 / 09 / 14$ & 102 & & & $29 / 05 / 15$ & 346 \\
\hline \multirow[t]{8}{*}{$18 / 02 / 14$} & & $13 / 05 / 14$ & 84 & & & $21 / 10 / 14$ & 135 & & & $22 / 06 / 15$ & 370 \\
\hline & & $13 / 06 / 14$ & 115 & & & $04 / 11 / 14$ & 149 & & & $30 / 07 / 15$ & 416 \\
\hline & & $14 / 07 / 14$ & 146 & & & $17 / 12 / 14$ & 192 & Cohort H & 07/10/14 & 07/10/14 & 63 \\
\hline & & $05 / 08 / 14$ & 168 & & & $21 / 01 / 15$ & 227 & $05 / 08 / 14$ & & $21 / 11 / 14$ & 110 \\
\hline & & $03 / 09 / 14$ & 197 & & & $24 / 02 / 15$ & 261 & & & $17 / 12 / 14$ & 136 \\
\hline & & $07 / 10 / 14$ & 231 & & & $31 / 03 / 15$ & 296 & & & $21 / 01 / 15$ & 171 \\
\hline & & $04 / 11 / 14$ & 259 & & & $28 / 04 / 15$ & 324 & Cohort I & $21 / 11 / 14$ & $21 / 11 / 14$ & 48 \\
\hline & & $17 / 12 / 14$ & 295 & & & $29 / 05 / 15$ & 355 & 03/09/2014 & & $17 / 12 / 14$ & 64 \\
\hline Cohort C & $13 / 05 / 14$ & $13 / 05 / 14$ & 69 & & & $22 / 06 / 15$ & 379 & & & $21 / 01 / 15$ & 99 \\
\hline \multirow[t]{6}{*}{$05 / 03 / 14$} & & 05/08/14 & 153 & Cohort F & $19 / 08 / 14$ & $19 / 08 / 14$ & 67 & & & $24 / 02 / 15$ & 133 \\
\hline & & $21 / 10 / 14$ & 230 & $13 / 06 / 14$ & & 03/09/14 & 82 & & & $31 / 03 / 15$ & 168 \\
\hline & & $17 / 12 / 14$ & 287 & & & $21 / 10 / 14$ & 130 & & & $28 / 04 / 15$ & 196 \\
\hline & & $21 / 01 / 15$ & 322 & & & $04 / 11 / 14$ & 144 & & & $29 / 05 / 15$ & 227 \\
\hline & & & & & & $17 / 12 / 14$ & 187 & & & & \\
\hline & & & & & & $21 / 01 / 15$ & 222 & & & & \\
\hline
\end{tabular}


Table 2. Mean values ( \pm S.D.) of total length (TL, mm) and total weight (TW, g) of Mimachlamys varia at the beginning and end of the study; Absolute and Specific Growth Rate (AGR and SGR, respectively) determined by the total length and total weight of each cohort studied. Each cohort was indicated with an alphabetic letter and with the immersion collector period.

\begin{tabular}{|c|c|c|c|c|c|c|c|c|c|}
\hline & $\begin{array}{l}\text { Cohort A } \\
\text { (January) }\end{array}$ & $\begin{array}{l}\text { Cohort B } \\
\text { (February) }\end{array}$ & $\begin{array}{l}\text { Cohort C } \\
\text { (March) }\end{array}$ & $\begin{array}{c}\text { Cohort D } \\
\text { (April) }\end{array}$ & $\begin{array}{l}\text { Cohort E } \\
\text { (May) }\end{array}$ & $\begin{array}{l}\text { Cohort F } \\
\text { (June) }\end{array}$ & $\begin{array}{l}\text { Cohort G. } \\
\text { (July) }\end{array}$ & $\begin{array}{l}\text { Cohort H } \\
\text { (August) }\end{array}$ & $\begin{array}{c}\text { Cohort I } \\
\text { (September) }\end{array}$ \\
\hline Inizial TL (mm) & $17.0 \pm 2.0^{\mathrm{c}}$ & $12.7 \pm 1.8^{\mathrm{a}}$ & $26.8 \pm 2.3 \mathrm{~g}$ & $24.2 \pm 2.4^{\mathrm{f}}$ & $20.0 \pm 2.4^{\mathrm{d}}$ & $13.7 \pm 2.1^{c}$ & $14.1 \pm 1.2^{b}$ & $17.7 \pm 1.3^{c}$ & $22.3 \pm 0.2^{\mathrm{e}}$ \\
\hline Final TL (mm) & $48.5 \pm 3.1^{\mathrm{e}}$ & $41.4 \pm 3.3^{c}$ & $44.4 \pm 3.0^{\mathrm{d}}$ & $46.5 \pm 2.8 \mathrm{~d}, \mathrm{e}$ & $44.0 \pm 2.1^{\mathrm{d}}$ & $31.9 \pm 3.3^{\mathrm{a}}$ & $40.2 \pm 3.0^{\mathrm{c}}$ & $33.1 \pm 2.7^{\mathrm{a}}$ & $36.7 \pm 3.3^{b}$ \\
\hline AGRl mm /day & $0.088 \pm 0.1^{\mathrm{d}, \mathrm{e}}$ & $0.097 \pm 0.2^{\mathrm{e}}$ & $0.055 \pm 0.1^{\mathrm{a}}$ & $0.082 \pm 0.1^{\mathrm{c}, \mathrm{d}, \mathrm{e}}$ & $0.063 \pm 0.0^{a, b}$ & $0.083 \pm 0.1^{b, c, d}$ & $0.063 \pm 0.01^{\mathrm{a}, \mathrm{b}}$ & $0.095 \pm 0.0^{\mathrm{e}}$ & $0.063 \pm 0.1^{\mathrm{a}, \mathrm{b}}$ \\
\hline SGRI (\%) & $0.29 \pm 0.07^{b, c}$ & $0.40 \pm 0.09^{c}$ & $0.16 \pm 0.07^{\mathrm{a}}$ & $0.24 \pm 0.05^{\mathrm{a}, \mathrm{b}}$ & $0.21 \pm 0.07^{\mathrm{a}, \mathrm{b}}$ & $0.38 \pm 0.06^{c}$ & $0.25 \pm 0.06^{\mathrm{a}, \mathrm{b}}$ & $0.38 \pm 0.08^{c}$ & $0.22 \pm 0.05^{a, b}$ \\
\hline Inizial TW (g) & $0.64 \pm 0.3^{b}$ & $0.30 \pm 0.1^{\mathrm{a}}$ & $2.50 \pm 0.8^{\mathrm{f}}$ & $2.00 \pm 0.6^{\mathrm{e}}$ & $1.00 \pm 0.3^{c}$ & $0.36 \pm 0.1^{b}$ & $0.44 \pm 0.2^{\mathrm{a}}$ & $0.76 \pm 0.3^{b}$ & $1.40 \pm 0.4^{\mathrm{d}}$ \\
\hline Final TW(g) & $13.9 \pm 3.0^{\mathrm{e}, \mathrm{f}}$ & $9.46 \pm 1.9^{\mathrm{d}}$ & $10.66 \pm 1.8^{\mathrm{e}}$ & $12.2 \pm 2.4^{\mathrm{f}}$ & $9.24 \pm 1.2^{\mathrm{d}}$ & $4.14 \pm 1.1^{\mathrm{a}}$ & $7.45 \pm 1.5^{c}$ & $4.74 \pm 1.0^{\mathrm{a}}$ & $5.75 \pm 1.3^{\mathrm{b}}$ \\
\hline AGRw g/day & $0.037 \pm 0.01^{\mathrm{d}, \mathrm{e}}$ & $0.031 \pm 0.00^{\mathrm{c}, \mathrm{d}, \mathrm{e}}$ & $0.025 \pm 0.00^{b, c}$ & $0.037 \pm 0.01^{\mathrm{e}}$ & $0.022 \pm 0.01^{b, c}$ & $0.017 \pm 0.00^{a}$ & $0.017 \pm 0.00^{\mathrm{a}}$ & $0.026 \pm 0.01^{\mathrm{c}, \mathrm{d}}$ & $0.019 \pm 0.01^{a, b}$ \\
\hline SGRw $(\%)$ & $0.88 \pm 0.09^{c}$ & $1.17 \pm 0.18^{\mathrm{d}}$ & $0.45 \pm 0.08^{a}$ & $0.66 \pm 0.08^{b, c}$ & $0.59 \pm 0.10^{\mathrm{a}, \mathrm{b}}$ & $1.10 \pm 0.12^{c}$ & $0.68 \pm 0.12^{b, c}$ & $1.12 \pm 0.14^{\mathrm{d}}$ & $0.62 \pm 0.06^{b}$ \\
\hline
\end{tabular}

Different letters $(\mathrm{a}, \mathrm{b}, \mathrm{c}, \mathrm{d}, \mathrm{e}, \mathrm{f})$ within a row denote significant differences $(p<0.05)$ 
Cohort A reached the highest length value $(48.5 \mathrm{~mm})$ after 357 days of culture, followed by cohort $\mathrm{D}$, which reached $46.5 \mathrm{~mm}$ after 273 days of culture, although the latter started with larger juveniles (Tables 1 and 2).

Coh B-Feb and Coh H-Aug both exhibited the highest absolute growth rate (AGRl: 0.097 and $0.095 \mathrm{~mm} \mathrm{day}^{-1}$, respectively) and specific growth rates (SGRls: $0.40 \%$ and $0.38 \%$, respectively), such as Coh F-Jun, which showed a value SGRl of $0.38 \%$. The absolute growth rate determined by weight (AGRw) was significantly higher in Coh A-Jan and Coh D-Apr (0.037), followed by Coh B-Feb with $0.031 \mathrm{~g}$ day $^{-1}$. SGRw exhibited the highest value in cohorts $\mathrm{B}$ and $\mathrm{H}$ with values of $1.17 \%$ and $1.12 \%$, respectively (Table 2).

There was a negative correlation between the mean TL determined at each sampling date and the temperature in cohorts $\mathrm{D}, \mathrm{E}, \mathrm{F}$ and $\mathrm{H}(p<0.05)$; the same relationship was showed with the mean total weight (TW) for cohorts C, D, E and F. A negative correlation was observed between dissolved oxygen and TL $(r=-0.71, p<0.05)$ and between dissolved oxygen and weight $(\mathrm{r}=-0.68 ; p<0.05)$ in cohort $\mathrm{G}$. A strong relationship was observed between $C h-a$ and TL in most aspects of the cohorts, such as the total weight $(p<0.05)$ (Table 3).

Table 3. Pearson's correlation between scallops' growth: TL (mm), weight (g) and environmental parameters (temperature, dissolved oxygen and chlorophyll) of the nine cohorts studied.

\begin{tabular}{ccccc}
\hline & & Temperature $\left({ }^{\circ} \mathrm{C}\right)$ & Dissolved Oxygen $(\%)$ & Ch-a $(\mu \mathrm{g} / \mathrm{L})$ \\
\hline \multirow{2}{*}{ Cohort A } & TL $(\mathrm{mm})$ & -0.33 & 0.09 & $0.81^{* * *}$ \\
& TW $(\mathrm{g})$ & -0.55 & 0.18 & $0.92^{* * *}$ \\
Cohort B & TL $(\mathrm{mm})$ & -0.14 & 0.15 & $0.81^{* * *}$ \\
& TW $(\mathrm{g})$ & -0.42 & 0.25 & $0.92^{* * *}$ \\
Cohort C & TL $(\mathrm{mm})$ & -0.37 & 0.08 & $0.83^{* * *}$ \\
& TW $(\mathrm{g})$ & $-0.80^{* *}$ & 0.3 & $0.93^{* * *}$ \\
Cohort D & TL $(\mathrm{mm})$ & $-0.78^{*}$ & 0.27 & $0.85^{* * *}$ \\
& TW $(\mathrm{g})$ & $-0.88^{* * *}$ & 0.23 & -0.16 \\
Cohort E & TL $(\mathrm{mm})$ & $-0.76^{*}$ & 0.39 & $0.63^{*}$ \\
& TW $(\mathrm{g})$ & $-0.72^{* * *}$ & 0.26 & 0.57 \\
Cohort F & TL $(\mathrm{mm})$ & $-0.94^{*}$ & 0.76 & $0.99^{* * *}$ \\
& TW $(\mathrm{g})$ & $-0.85^{* * *}$ & 0.24 & $0.96^{* * *}$ \\
Cohort G & TL $(\mathrm{mm})$ & 0.06 & $-0.71 *$ & -0.12 \\
& TW $(\mathrm{g})$ & 0.26 & $-0.68^{*}$ & -0.26 \\
Cohort H & TL $(\mathrm{mm})$ & $-0.91^{*}$ & -0.87 & $0.87^{* * *}$ \\
& TW $(\mathrm{g})$ & -0.83 & -0.75 & $0.92^{* * *}$ \\
Cohort I & TL $(\mathrm{mm})$ & -0.7 & 0.49 & 0.16 \\
& TW $(\mathrm{g})$ & -0.56 & 0.58 & 0.02 \\
\hline
\end{tabular}

${ }^{*}$ relationship $(p \leq 0.05) ;{ }^{* *}$ significant relationship $(p \leq 0.01) ;{ }^{* * *}$ most significant relationship $(p \leq 0.005)$; n.s., no relation.

Length-weight relathionship (LWR) equations suggested that weight increased with negative allometry in most aspects of the cohorts, except for Coh A-Jan, which showed an isometric growth with $\mathrm{a}$ coefficient $\mathrm{b}$ of $2.95 \pm 0.24\left(\mathrm{R}^{2}=0.77 ; t\right.$-test, $\left.p=0.65\right)$. The values of the allometric coefficient $\mathrm{b}$ varied between $2.54 \pm 0.20$ (Coh H-Aug) and $2.77 \pm 0.07$ (Coh F-Jun) with correlation coefficients ranging from 0.82 to 0.95 , indicating a strong relationship between TL and TW ( $t$-test, $p<0.05)$ (Table 4). 
Table 4. Descriptive statistics and estimated parameters of Weight-Length relationships of Mimachlamys varia cultured in the Ionian Sea.

\begin{tabular}{|c|c|c|c|c|c|}
\hline \multirow{2}{*}{ Months } & \multirow{2}{*}{$\mathbf{N}$} & \multicolumn{3}{|c|}{$\mathbf{W}=\mathrm{aTL}^{\mathrm{b}}$} & \multirow{2}{*}{$\frac{p \text {-Value }}{(t \text {-Test })}$} \\
\hline & & $a \pm S . E$. & $\boldsymbol{b} \pm S . E$ & $\mathbf{R}^{2}$ & \\
\hline Cohort A (January) & 200 & $0.28 \pm 0.08$ & $2.95 \pm 0.24$ & 0.77 & 0.65 \\
\hline Cohort B (February) & 254 & $0.21 \pm 0.03$ & $2.64 \pm 0.11$ & 0.84 & 0.005 \\
\hline Cohort C (March) & 150 & $0.19 \pm 0.03$ & $2.69 \pm 0.11$ & 0.92 & 0.008 \\
\hline Cohort D (April) & 196 & $0.18 \pm 0.02$ & $2.71 \pm 0.08$ & 0.82 & 0.003 \\
\hline Cohort E (May) & 285 & $0.21 \pm 0.03$ & $2.61 \pm 0.11$ & 0.84 & 0.003 \\
\hline Cohort F (June) & 149 & $0.18 \pm 0.02$ & $2.77 \pm 0.07$ & 0.94 & 0.005 \\
\hline Cohort G (July) & 284 & $0.19 \pm 0.03$ & $2.68 \pm 0.08$ & 0.89 & 0.002 \\
\hline Cohort H (August) & 90 & $0.25 \pm 0.09$ & $2.54 \pm 0.20$ & 0.85 & 0.02 \\
\hline Cohort I (September) & 160 & $0.17 \pm 0.01$ & $2.69 \pm 0.05$ & 0.95 & 0.0004 \\
\hline
\end{tabular}

$\mathrm{N}$ = sample size; $\mathrm{a}=$ Intercept; $\mathrm{b}=$ Slope; S.E. = Standard Error; $\mathrm{R}^{2}$ = Coefficient of Determination; $p$-value for $t$-test.

The growth of $M$. varia described by the parameters of the von Bertalanffy equation- $\mathrm{L}_{\infty}, \mathrm{K}$, to and $\varphi^{\prime}$-is shown in Table 5 and Figure 4 . The von Bertalanffy growth model showed a sustained growth increase throughout the study period. The estimated maximum lengths were, 52.2, 51.2 and 50.3 in cohorts A, D and B, respectively, but the instantaneous growth coefficient was highest in cohort $\mathrm{H}$ $(\mathrm{K}=0.91)$. The growth performance index $\left(\varphi^{\prime}\right)$, used to compare the growth of the cohorts studied, ranged between 2.52 (Coh F-June) and 3.03 (Coh H-August) (Table 2).

Table 5. Von Bertalanffy growth parameters $(\mathrm{L} \infty, \mathrm{K}$, to) of $M$. varia and index of growth performance $\left(\phi^{\prime}\right)$ were fitted from growth data of each study cohorts. Each cohort was indicated with an alphabetic letter and with the immersion collector period.

\begin{tabular}{ccccc}
\hline & $\mathbf{L}_{\infty}(\mathbf{~ m m})$ & K year $^{-1}$ ) & to (year) & $\boldsymbol{\phi}^{\prime}$ \\
\hline Cohort A (Jane) & 52.2 & 0.35 & 0.75 & 2.98 \\
Cohort B (February) & 50.28 & 0.14 & 0.07 & 2.56 \\
Cohort C (March) & 45.81 & 0.33 & 0.5 & 2.84 \\
Cohort D (April) & 51.2 & 0.32 & 0.8 & 2.92 \\
Cohort E (May) & 45.15 & 0.3 & 0.49 & 2.79 \\
Cohort F (June) & 37.98 & 0.23 & 0.05 & 2.52 \\
Cohort G (July) & 43.94 & 0.22 & 0.35 & 2.63 \\
Cohort H (August) & 34.18 & 0.91 & 1.15 & 3.03 \\
Cohort I (September) & 42.24 & 0.27 & 0.24 & 2.68 \\
\hline
\end{tabular}



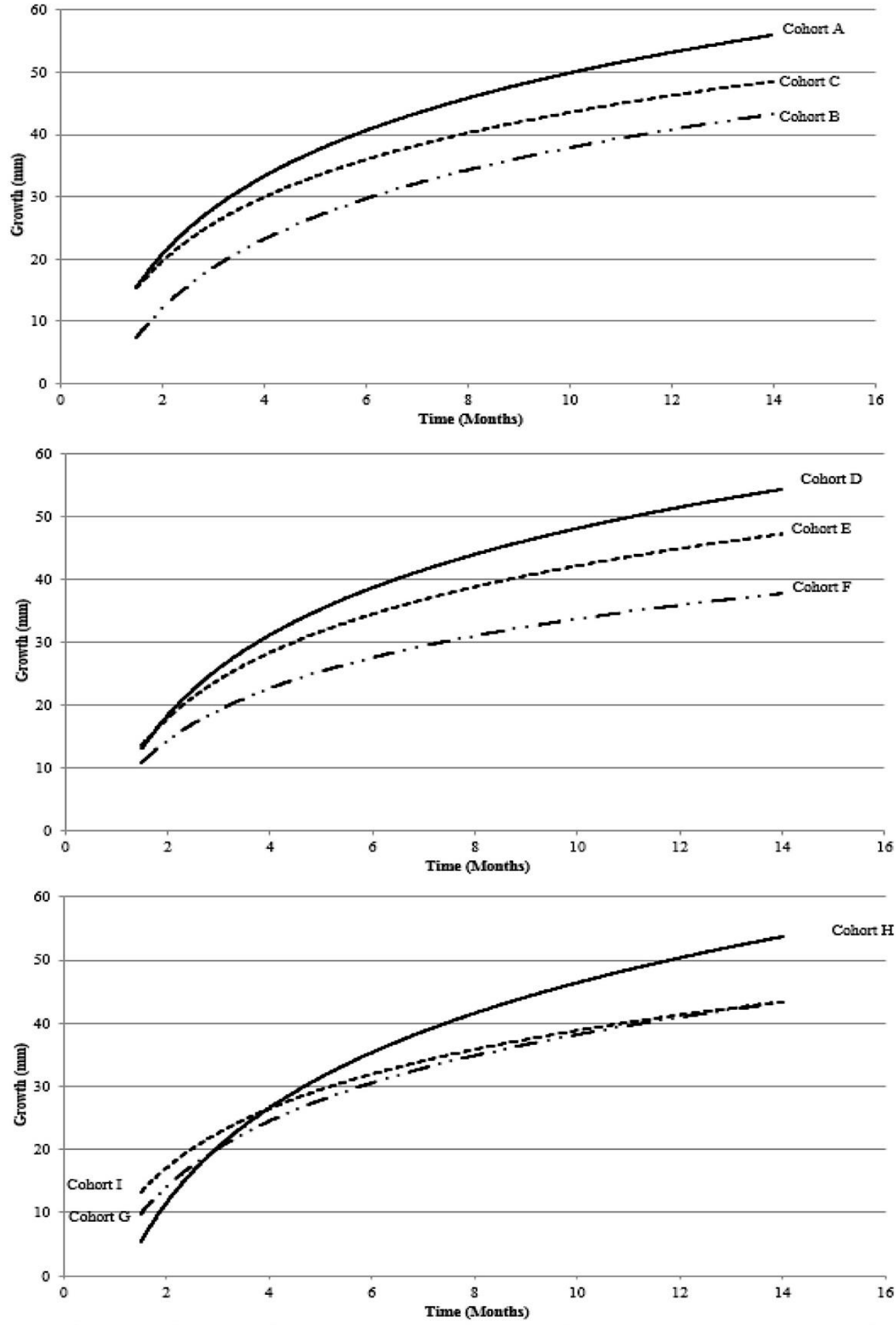

Figure 4. Von Bertalanffy growth curves obtained for the nine Mimachlamys varia cohorts studied.

\section{Discussion}

The results of this study show different growth rates in the cohorts studied, which could be explained by the seasonal fluctuations of the considered environmental variables.

Temperature and food availability are typically considered to be among the main factors affecting the physiology, gene expression, distribution, and fitness of bivalves [23-25]. A relatively strong 
correlation between growth and these parameters was found. Temperature correlated negatively with growth in the cohorts born in spring and early summer, when temperatures were higher.

In general, as temperature increases, physiological rates increase until a threshold is met, at which point it is possible to observe a decline [25]. Therefore, decreased growth in the summer months can mainly be attributed to exposure to temperatures beyond the optimum for growth of the species $\left(22{ }^{\circ} \mathrm{C}\right)[26]$.

Previous work reported that growth for several bivalves is correlated with food availability [27], which could be affected by current velocity, mesh of cages and fouling [28,29]. The results of this study show that most of the M. varia cohorts' growth is positively correlated with the seasonal fluctuation of chlorophyll-a, indicating higher growth rates in periods of relatively higher food abundance and with lower temperatures. Dissolved oxygen concentration only affected the growth of cohort $\mathrm{G}$ (born in July) at times of high temperatures; this situation could have caused a decrease in oxygen solubility, which can affect scallops' ability to respire and metabolize energy [30,31]. Therefore, the combination of temperature, chlorophyll-a concentration, dissolved oxygen, and probably also other environmental variables not considered in this study contributes to scallop growth variation in the area studied.

Grow-out of pectinidae on the suspended cages has been successfully developed in Australia [32], Chile [33] and Great Britain [34,35]. Based on the available literature, the growth rate of M. varia in suspended cultures was similar to that obtained in other species of commercially cultured pectinids around the world. For example, Patinopecten yessoensis [36], Argopecten ventricosus [37,38], Argopecten irradians [39], Aequipecten opercularis [35] and Mimachlamys asperrima [40] reach the commercial size of 50-60 mm after 8-12 months in culture. In the Mediterranean Sea, RATHMAN et al. [9] studied the growth of juvenile M. varia in the Mali Stone bay (Southern Adriatic), reporting that specimen size varied depending on rearing depth: at $5 \mathrm{~m}$, scallops from the initial size of $10.9 \mathrm{~mm}$ TL reached $41.90 \mathrm{~mm}$ after 22 months of culture. Marguš et al. [41] reported the growth of juvenile M. varia from its initial size of 16.4-17.6 mm to 42.7-47.5 mm during a one-year period (12 months) in the Krka river (Adriatic Sea, Croatia).

The results of this study seem to be favorable enough since the scallops had a fast growth; the smallest scallops, with an average length of $12.7 \mathrm{~mm}$ (Coh B-Feb), were transferred to the culture in April and reached $41.4 \mathrm{~mm}$ in 9 months (December). Similar results were obtained from the largest juveniles, which were about $24.2 \mathrm{~mm}$ (Coh D-Apr) and were inserted into cages in June, where they reached the size of $46.5 \mathrm{~mm}$ in 9 months (December).

The index of "absolute growth rate" (AGR) and "specific growth rate", used to compare growth among cohorts, showed that the highest mean growth rate occurred in the cohorts born in the winter-spring months. This indicates the possibility of farmers utilizing $M$. varia spats born in the winter and introducing them in suspended cages for on-growing in the spring to benefit from the low temperatures favorable to the growth of this species.

However, Coh H-Aug also showed a high AGR value, but this result must be taken with caution because it considers only the first 5 months of culture, and during the first juvenile stages growth accelerates more than in adult stages.

Shell growth, both in length and mass, of the nine M. varia cohorts followed a linear trend with a strong relationship between length and weight (LWR), indicating negative allometric growth (except for Coh A-Jan) and signifying that individuals grow relatively faster in length than in weight. Similar results are reported for the same species in Lanveoc, Bay of Brest, France [42] and in the Gulf of Gerence (Aegean Sea) [43]. Correlation coefficients ranged from 0.82 to 0.95 , indicating a strong relationship between TL and TW.

The conventional von Bertalanffy growth model has been reported as suitable for describing the growth of molluscs $[44,45]$. Differences in the growth parameters of $M$. varia among the cohorts studied were observed. The highest $\mathrm{K}$ values were evident in the winter and spring cohorts (except for Coh B-Feb). In the summer, when the temperature increased, the growth of $M$. varia reduced. This behavior was observed for the same species by Burnell (1995) [11], who reports that high 
temperatures, particularly in the summer, negatively influence growth and survival due to stress and susceptibility to diseases.

Cano et al. [46] reported a higher $\mathrm{K}$ value than those found in this study for M. varia cultured in suspended cages in Fuengirola (Malaga, Spain) (1.16). Taylor et al. [30] reported similar values of K (0.30-0.38) for Nodipecten subnodosus cultured in the Baja California Peninsula.

Growth performance parameters $\left.\left(\phi^{\prime}\right)\right)$ were used to compare the growth of $M$. varia with other pectinidae studies. In Baja California Peninsula, Nodipecten subnodosus showed growth performance within 3.93-4.12 values [47,48]; peruvian scallop Argopecten purpuratus showed $\varphi$ values in the range of 3.68-4.56 [48]; and Placopecten magellanicus in the Great South Channel, USA, showed $\phi^{\prime}$ in a range of 3.6-4.0 [49,50]. However, it is necessary to consider that utilizing VBGF and $\phi^{\prime}$ parameters to compare the results of scallops' growth with previous studies may be misleading, since differences in environmental conditions between scallop stocks and in culture techniques exist.

\section{Conclusions}

The results show that $M$. varia in the Gulf of Taranto has satisfactory growth performance in suspended cages, providing the possibility of starting cultures in the near future in the Mediterranean Sea. This can lead to an expansion of aquaculture in the European Union, based on fast growth of $M$. varia in a smart way, namely, without use of gear (dredges and trawls) that cause considerable damage and disturbance to benthic communities. For example, beam trawling and scallop dredging cause serious biological impact on sessile organisms, such as erect organisms like sponges and corals, which decrease considerably with the passing of ground gear.

This study presents the possibility of fishermen cultivating the species at optimum times by, for example, introducing caged juveniles in spring and late autumn to benefit from low temperatures, which are favorable to the growth of this species. Moreover, high spat availability during the whole year makes the Gulf of Taranto a good nursery area to develop a scallops' culture [12].

Author Contributions: Conceptualization, E.P. and G.F.; Methodology, E.P., G.F.; F.B. and I.P.; investigation, F.B., I.P.; L.P. and G.D.; data curation, E.P., L.P., G.F.; writing-original draft preparation, E.P., I.P., G.F.; L.P. and I.B. writing-Review and editing, E.P. supervision, E.P.; project administration G.F. and E.P.; All authors have read and agreed to the published version of the manuscript.

Funding: This study was carried out within the framework of the REPAIR project, supported by FEP Apulia Region 2007-2013 (Code: 17/OPI/010).

Conflicts of Interest: The authors declare no conflict of interest.

\section{References}

1. European Commission. Strategic Guidelines for the sustainable development of EU aquaculture. Communication from the Commission to The European Parliament, The Council, The European Economic and Social Committee and the Committee of the Regions. COM 2013299 Final. Available online: http://ec.europa.eu/fisheries/cfp/aquaculture/official_documents/com_2013_229_en.pdf (accessed on 27 November 2020).

2. Klinger, D.H.; Eikeset, A.M.; Davíðsdóttir, B.; Winter, A.M.; Watson, J.R. The mechanics of blue growth: Management of oceanic natural resource use with multiple, interacting sectors. Mar. Policy 2018, 87, 356-362. [CrossRef]

3. Bostock, J.; Lane, A.; Hough, C.; Yamamoto, K. An assessment of the economic contribution of EU aquaculture production and the influence of policies for its sustainable development. Aquac. Int. 2016, 24, 699-733. [CrossRef]

4. Manthey-Karl, M.; Lehmann, I.; Ostermeyer, U.; Rehbein, H.; Schröder, U. Meat Composition and Quality Assessment of King Scallops (Pecten maximus) and Frozen Atlantic Sea Scallops (Placopecten magellanicus) on a Retail Level. Foods 2015, 4, 524-546. [CrossRef]

5. Telahigue, K.; Chetoui, I.; Imen, R.; Romdhane, M.S.; El Cafsi, M. Comparative fatty acid profiles in edible parts of wild scallops from the Tunisian coast. Food Chem. 2010, 122, 744-746. [CrossRef] 
6. Turolla, E. La venericoltura in Italia. In Estado Actual Del Cultivo Y Manejo De Moluscos Bivalvos Y Su Proyecci On Futura. Factores Que Afectan Su Sustentabilidad En America Latina; Lovatelli, A., Farıs, A., Uriarte, I., Eds.; FAO: Roma, Italy, 2008; pp. 177-188.

7. Kaiser, M.J.; Clarke, K.R.; Hinz, H.; Austen, M.C.V.; Somerfield, P.J.; Karakassis, I. Global analysis of response and recovery of benthic biota to fishing. Mar. Ecol. Prog. Ser. 2006, 311, 1-14. [CrossRef]

8. Louro, A.; De La Roche, J.P.; Campos, M.J.; Roman, G. Hatchery rearing of the black scallop Chlamys varia (L.). J. Shellfish Res. 2003, 22, 95-99.

9. Rathman, M.; Bolotin, J.; Glavić, N.; Barišić, J. Influence of water depth on growth and mortality of Chlamys varia (Linnaeus, 1758): Implications for cage culture in Mali Ston Bay, Croatia. Aquacult. Int. 2017, 25, 135-146. [CrossRef]

10. Rodhouse, P.G.; Burnell, G.M. In situ studies on the scallop Chlamys varia. In Progress in Underwater Science; Gamble, J.C., George, J.D., Eds.; Pentech Press: Plymouth, UK, 1979; p. 220.

11. Burnell, G.M. Age-related protandry in the scallop Chlamys varia on the west coast of Ireland. ICES Mar. Sci. 1995, 199, 26-30.

12. Prato, E.; Biandolino, F.; Parlapiano, I.; Gianguzza, P.; Fanelli, G. The recruitment of scallops (and beyond) by two different artificial collectors (Gulf of Taranto, Mediterranean Sea). Aquac. Res. 2016, 47, 3319-3331. [CrossRef]

13. Prato, E.; Danieli, A.; Maffia, M.; Biandolino, F. Lipid and fatty acid compositions of Mytilus galloprovincialis cultured in the Mar Grande of Taranto (Southern Italy): Feeding strategies and trophic relationships. Zool. Stud. 2010, 49, 211-219.

14. Prato, E.; Biandolino, F. Total lipid content and fatty acid composition of commercially important fish species from the Mediterranean, Mar Grande Sea. Food Chem. 2012, 131, 1233-1239. [CrossRef]

15. Strickland, J.D.H.; Parsons, T.R. A Practical Handbook of Sea Water Analysis; Fisheries Research Board of Canada: Ottawa, PE, Canada, 1972; p. 311.

16. Pearce, C.M.; Manuel, J.L.; Gallager, S.M.; Manning, D.A.; O'dor, R.K.; Bourget, E. Depth and timing of settlement of veligers from different populations of giant scallop, Placopecten magellanicus (Gmelin), in thermally stratified mesocosms. J. Exp. Mar. Biol. Ecol. 2004, 312, 187-214. [CrossRef]

17. Wootton, R.J. Ecology of Teleost Fishes; Springer Science and Business Media LLC.: Heidelberg, Germany, 1989; pp. 1-404.

18. Ricker, W.E. Computation and interpretation of biological statistics of fish populations. B Fish. Res. Board Can. 1975, 191, 1-382.

19. Von Bertalanffy, L. Untersuchungeun uber die Gesetzlichkeit des Wachstums I. Roux' Arch. 1934, 131, $613-652$. [CrossRef]

20. Gayanilo, F.C., Jr.; Sparre, P.; Pauly, D. The FAO-ICLARM Stock Assessment Tools II (FISAT II). Revised Version. User's Guide. FAO Computerized Information Series (Fisheries) 8; FAO: Rome, Italy, 2005; p. 126.

21. Munro, J.L.; Pauly, D. A Simple Method for comparing growth of fishes and invertebrates. ICLARM Fishbyte 1983, 1, 5-6.

22. Pauly, D.; Munro, L. Once more on the comparison of growth in Fish and Invertebrate. Fishbyte 1984, 2, 1-21.

23. Bayne, B.; Newell, R. Physiological Energetics of Marine Molluscs. In The Mollusca; Saleuddin, A.S.M., Wilbur, K.M., Eds.; Elsevier BV: Amsterdam, The Nehterlands, 1983; pp. 407-515.

24. Zippay, M.L.; Helmuth, B. Effects of temperature change on mussel, Mytilus. Integr. Zoöl. 2012, 7, $312-327$. [CrossRef]

25. Shelmerdine, R.L.; Mouat, B.; Shucksmith, R. The most northerly record of feral Pacific oyster Crassostrea gigas (Thunberg, 1793) in the British Isles. BioInvasions Rec. 2017, 6, 57-60. [CrossRef]

26. Koch, V.; Rengstorf, A.; Taylor, M.; Mazón-Suástegui, J.M.; Sinsel, F.; Wolff, M. Comparative growth and mortality of cultured Lion's Paw scallops (Nodipecten subnodosus) from Gulf of California and Pacific populations and their reciprocal transplants. Aquac. Res. 2015, 46, 185-201. [CrossRef]

27. MacDonald, B.A.; Thompson, R.J. Influence of temperature and food availability on the ecological energetics of the giant scallop Placopecten magellanicus II. Reproductive output and total production. Mar. Ecol. Progr. Ser. 1985, 25, 295-303. [CrossRef]

28. Lodeiros, C.J.M.; Himmelman, J.H. Influence of fouling on the growth and survival of the tropical scallop, Euvola (Pecten) zic zac (L. 1758) in suspended culture. Aquac. Res. 1996, 27, 749-756. [CrossRef] 
29. Lodeiros, C.; Pico, D.; Prieto, A.; Narváez, N.; Guerra, A. Growth and survival of the pearl oyster Pinctada imbricata (Röding 1758) in suspended and bottom culture in the Golfo de Cariaco, Venezuela. Aquacult. Int. 2002, 10, 327-338. [CrossRef]

30. Purce, D.N.S. Evaluation of different shallow water culture methods for the scallop Nodipecten subnodosus using biologic and economic modeling. Aquaculture 2006, 254, 301-316. [CrossRef]

31. Purce, D.N.S. Comparative Ecophysiology of Two Geographically Separated Populations of the Scallop. Master's Thesis, Western Washington University, Bellingham, WA, USA, 2007; p. 84.

32. Gwyther, D.; Cropp, D.A.; Joll, L.M.; Dredge, M.C.L. Scallops in Australia. In Scallops: Biology, Ecology and Aquaculture; Shumway, S.E., Ed.; Elsevier: Amsterdam, The Netherlands, 1991; p. 1500.

33. Navarro-Piquimil, R.; Sturla-Figueroa, L.; Cordero-Contreras, O.; Avendaño, D. Chile. In Scallops: Biology, Ecology and Aquaculture; Shumawy, S.E., Ed.; Elsevier: Amsterdam, The Netherlands, 1991; Volume 21, p. 1500.

34. Mason, J. Scallop and Queen Fisheries in the British Isles; Fishing News Books Limited: Farnham, UK, $1983 ;$ p. 144.

35. Ansell, A.D.; Dao, J.C.; Mason, J. Three European scallops: Pecten maximus, Chlamys (Aequipecten) opercularis and C. (Chlamys) varia. In Scallops: Biology, Ecology and Aquaculture; Shumway, S.E., Ed.; Elsevier: Amsterdam, The Netherlands, 1991; pp. 715-751.

36. Ito, H. Japan: Fisheries and aquaculture. In Scallops: Biology, Ecology and Aquaculture; Shumway, S.E., Ed.; Elsevier: Amsterdam, The Netherlands, 1991; pp. 1017-1055.

37. Maeda-Martínez, A.N.; Reynoso-Granados, T.; Monsalvo-Spencer, P.; Sicard, M.T.; Mazón-Suástegui, J.M.; Hernandez, O.; Segovia, E.; Morales, R. Suspension culture of catarina scallop Argopecten ventricosus (=circularis) (Sowerby II, 1842), in Bahia Magdalena, Mexico, at different densities. Aquaculture 1997, 158, 235-246. [CrossRef]

38. Félix-Pico, E.F.; And Tripp-Quezada, A.; Castro-Ortiz, J.L.; Serrano-Casillas, G.; Gonzalez-Ramìrez, P.G.; Villalejo-Fuerte, M.; Palomares-García, R.; García-Dominguez, F.A.; Mazón-Suástegui, M.; Bojorquez-Verástica, G.; et al. Repopulation and culture of the Pacific calico scallop in Bahía Concepción, Baja California Sur, México. Aquacult. Int. 1997, 5, 551-563. [CrossRef]

39. Barber, B.J.; Davis, C.V. Growth and mortality of cultured bay scallops in the Damariscotta River, Maine (USA). Aquac. Int. 1997, 5, 451-460. [CrossRef]

40. O'connor, W.A.; Heasman, M.P.; O'Connor, S.J. Suspended culture of Dougboy scallops Mimachlamys asperrima (Lamarck). J. World Aquacul. Soc. 1997, 28, 171-179. [CrossRef]

41. Marguš, D.; Teskeredžić, E.; Teskeredžić, Z.; Tomec, M. Prihvat Ličinki, Preživljavanje I Rast Mlađi Malih Kapica (Chlamys varia Linnaeus, 1758) U Kontroliranom Uzgoju U Uvali Šarina Draga-Ušće Rijeke Krke. Ribarstvo Croat. J. Fish. 2005, 63, 91-103.

42. Conan, G.; Shafee, S.M. Growth and biannual recruitment of the black scallop Chlamys varia (L.) in lanveoc area, Bay of Brest. J. Exp. Mar. Biol. Ecol. 1978, 35, 59-71. [CrossRef]

43. Ozvarol, Y.; Gokoglu, M. Some Biological Aspects of Scallop Chlamys varia (Linnaeus, 1758), (Bivalvia: Pectinida) from Aegean Sea coast of Turkey. J. Appl. Biol. Sci. 2013, 7, 68-70.

44. Pirlot, A.S.; Wolff, M. Population dynamics and fisheries potential of Anadara tuberculosa (Bivalvia: Arcidae) along the Pacific coast of Costa Rica. Rev. Biol. Trop. 2006, 54, 87-99.

45. Amin, S.; Zafar, M.; Halim, A. Age, growth, mortality and population structure of the oyster, Crassostrea madrasensis, in the Moheskhali Channel (southeastern coast of Bangladesh). J. Appl. Ichthyol. 2008, 24, 18-25. [CrossRef]

46. Cano, J.; Campos, M.J.; López, F.J.; Saavedra, M. Utilización de distintos sistemas de engorde en el cultivo de vieira Pecten maximus (L., 1758), zamburiña Mimachlamys varia (L., 1758) y volandeira Aequipecten opercularis (L., 1758) en Andalucía (España). Bol. Inst. Esp. Oceanogr. 2006, 21, 283-291.

47. Freites-Valbuena, L.F.; Mazòn-Suástegui, J.M.; Maeda-Martínez, A.N.; Koch, V.; Osuna-García, M.; Ruiz-Verdugo, C.A.; García-Domínguez, F.A.; De La Roche, J.P.; Manzoni, G.; Rupp, G.R.; et al. Preengorde, cultivo intermedio y engorde de los pectínidos Nodipecten nodosus y N. subnodosus. In Biología y Cultivo de los Moluscos Pectínidos del Género Nodipecten; Maeda-Martinez, A.N., Lodeiros, C., Eds.; Editorial Limusa: Monterrey, México, 2009; Volume 11, pp. 275-312.

48. Chauvaud, L.; Patry, Y.; Jolivet, A.; Cam, E.; Le Goff, C.; Strand, Ø.; Charrier, G.; Thébault, J.; Lazure, P.; Gotthard, K.; et al. Variation in Size and Growth of the Great Scallop Pecten maximus along a Latitudinal Gradient. PLoS ONE 2012, 7, e37717. [CrossRef] 
49. Mendo, J.; Jurado, E. Length-based growth parameter estimates of the Peruvian scallop (Argopecten purpuratus). Fish. Res. 1993, 15, 357-367. [CrossRef]

50. Harris, B.P.; Stokesbury, K.D. Shell growth of sea scallops (Placopecten magellanicus) in the southern and northern Great South Channel, USA. ICES J. Mar. Sci. 2006, 63, 811-821. [CrossRef]

Publisher's Note: MDPI stays neutral with regard to jurisdictional claims in published maps and institutional affiliations.

(C) 2020 by the authors. Licensee MDPI, Basel, Switzerland. This article is an open access article distributed under the terms and conditions of the Creative Commons Attribution (CC BY) license (http://creativecommons.org/licenses/by/4.0/). 